\title{
Description and assessment of a collaborative agricultural extension program adopted under the triple helix model of innovation
}

\author{
Sofía Boza, Macarena Espinoza, Ricardo Pertuzé, Marcos Mora, and \\ Karina Orellana \\ Faculty of Agricultural Sciences, University of Chile. Santiago, Chile.
}

\begin{abstract}
S. Boza, M. Espinoza, R. Pertuzé, M. Mora, and K. Orellana. 2021. Description and assessment of a collaborative agricultural extension program adopted under the triple helix model of innovation. Int. J. Agric. Nat. Resour. 248-258. The triple helix model (THM) studies the interactions between academia, industry, and government designed to promote entrepreneurship and innovation in a knowledge-based society. This paper shows how agricultural extension works through the THM for inclusive innovation to evaluate its effects on farmers. For this purpose, we analyze the case of Cultiva UChile, a technology transfer center led by the University of Chile that operated from 2016 to 2020 and that was financed by and in cooperation with public sector organizations. Cultiva UChile offered extension services to vegetable growers from the Chilean Central Valley. As our main sources of information, we used internal reports and surveys of 91 farmers who received Cultiva UChile extension services from 2019-2020. A qualitative study of this organization, the actors involved, and the operation and governance of the center and a quantitative analysis of the center's direct effects adopting descriptive techniques and binary logistic regression were used. The results show strong interactions between actors as the basis of Cultiva UChile and its positive short-term direct effects regardless of farmers' paths in terms of innovation, cooperation, and investment. These results lead us to conclude that extension services adopted under the THM can be appropriate means to promote inclusive innovation in agriculture.
\end{abstract}

Keywords: Direct effects, extension services, small-scale farming, vegetable growing.

\section{Introduction}

Universities have been reimagined since the 1990s as institutions that can generate industryrelevant knowledge and contribute to economic development. Researchers and policy-makers have focused on how universities can make direct and measurable contributions, especially to their lo-

Received Jan 18, 2021. Accepted Aug 11, 2021

Corresponding author: sofiaboza@u.uchile.cl cal economies (Breznitz \& Feldman, 2012). The triple helix model (THM) is used to study the interactions between academia, industry, and government intended to promote entrepreneurship and innovation in a knowledge-based society. Etzkowitz and Leydesdorff (1995) propose a pioneering theoretical framework for the THM. The authors postulate that increased cooperation between what they call the institutional sectors public, private, and academic - generates a spiral 
pattern of connections that form a key component of innovation strategies. In subsequent revisions of the THM, hybrid institutions such as technology transfer centers are essential intermediators of innovative ecosystems. Innovation based on the THM requires that, in some capacity, the institutions involved cooperate with each other's roles (Etzkowitz \& Zhou, 2017).

Etzkowitz and Leydesdorff (1995) identified the New England regional innovation system of the beginning of the twentieth century based on "strategic research" directed toward local industry development at the Massachusetts Institute of Technology as the earliest example of the THM. However, more widespread early examples of the THM may have been agricultural extension programs. Reddy (2011) points out that at the beginning of the twentieth century, the first agricultural universities forged close relationships with farmers to help increase their productivity through specialized research and technology sharing extension services. For a long time, however, the common approach to disseminating research and technology was an obstacle for innovation. Research and extension were seen as consecutive stages but were not interlinked (Röling, 1990). There thus emerged an interest in addressing agricultural innovation from a systemic perspective. The THM is an approach that analyzes agricultural innovation from the perspective of agricultural innovation systems (AISs) along with other proposals such as regional innovation systems, clusters, innovative ecosystems, or smart specialization (Klerkx et al., 2012).

Today, AISs worldwide rely on extension services working directly with research and development to increase farm productivity by disseminating best practices (Steensland \& Zeigler, 2021). Networking and mutual learning are essential parts of the AIS approach to generate innovation, with researchers and extension agents serving as key actors (Klerkx et al., 2010). Especially for impoverished, small-scale farmers, scientific research is not sufficient in developing an AIS, and there needs to be a strong focus on extension (Hellin \& Camacho, 2016).

Over the past decade, agricultural extension has moved from its traditional focus on technology transfer and farm management information to the use of a multiactor advisory service model, now covering topics such as marketing and sustainability (Norton \& Alwang, 2020). The relationships between universities and farmers built through comprehensive extension that go beyond the mere sharing of technical information help generate innovation and development in local agriculture. The public sector typically assumes a key role in financing agricultural extension services when they are considered an efficient mean to stimulate production and growth (Aron, 2003). In fact, most agricultural extension services worldwide are funded by the public sector, while private sector financing for extension services is relatively rare (Bruce \& Costa, 2019). The interactions between sectors described in the THM therefore serve as a framework for agricultural innovation through extension that, although it has evolved, persists. Universities can fill two roles simultaneously by acting as advisors and as "innovation brokers" that bring together participants of the innovation system (Knickel et al., 2021).

The THM involves being participatory, strategic, and adapting to local realities. When a THM reduces barriers for groups that have been left behind or purposefully excluded in the past and, in contrast, recognizes the advantages of their resources, capabilities, and knowledge, it promotes what is known as "inclusive innovation" (Yao et al., 2018), i.e., the inclusion of groups that are frequently excluded or dismissed, especially due to their limited economic means, within certain aspects of innovation such as impacts or processes (Heeks et al., 2014). Despite its potential, the study and empirical evidence of the role of the THM in inclusive innovation are limited, especially in the case of emerging and developing economies (Daniels et al., 2017). The current research on the THM in agriculture is focused 
on exploring the role of the institutional sectors involved and their interactions in specific cases (e.g., Dalmarco et al., 2019; Derunova, 2021; Yongabo \& Goktepe-Hulten, 2021). Some authors have proposed extending the model to include additional actors such as civil society and the environment in a quadruple or even quintuple helix model (Carayannis et al., 2017).

The objective of this article is to show how agricultural extension works when it is based on the THM for inclusive innovation; to evaluate its effects on farmers and to determine whether a farmer's prior recent experience with cooperation, innovation, and investment in physical capital affects the direct effects of extension services under the THM.

This research focuses on central Chile and considers the case of a horticultural extension center called Cultiva UChile. In 2016, economic development agency CORFO of the Chilean Ministry of Economy, Development, and Tourism called for proposals for technology transfer centers. These centers were required to stimulate the uptake of technology by companies and to increase product, process, marketing, and management innovation through extension. According to the last Innovation Survey of the Ministry of Economy (2018), the private innovation rate in Chile was only $15.1 \%$. Small-scale, nonexporting, and agricultural companies are the least innovative. CORFO decided to finance 13 technology transfer centers located in different regions and focused on diverse economic sectors (e.g., mining, tourism, construction, aquaculture, and agriculture). Cultiva UChile, one of the centers created following CORFO's call, was established from a proposal by the Faculty of Agricultural Sciences of the University of Chile. The center's objective was to increase the presence of vegetables in the Chilean food system. Cultiva UChile operated from 2016 to 2020 and focused on advising small-scale vegetable farmers from the Central Valley of Chile, and specifically the Santiago Metropolitan Region (SMR) and Libertador General Bernardo O’Higgins Region
(OHR), in four main areas: marketing and business management, the efficient use of resources, phytosanitary management, and cultivation and postharvest practices.

In Chile, important structural changes have been made to the agricultural sector in recent decades. Many of these changes have been market driven, as Chilean agricultural products were successfully launched into international markets starting in the 1990s. The fruit produced in the Chilean Central Valley serves as a paradigmatic example (Boza et al., 2020a). The export of agricultural products, however, has led to significant gaps between farmers. Those oriented toward the national market, as most vegetable growers are, have notoriously lacked key resources such as technology and access to funding (Echeverría et al., 2012). Meanwhile, even though cooperation makes it easier to innovate, small-scale farmers in Chile tend to isolate themselves (Geldes et al., 2017).

Within the research using the THM focused on Chile, Chacana et al. (2019) applied the model to study cooperation in the agri-food industry in the Coquimbo Region. The authors conclude that differing visions and objectives between organizations limit cooperation, while "social proximity," i.e., social relationships on a microscale level, facilitates it. Armando et al. (2017) applied the THM to analyze competitiveness factors of the Chilean wine cluster in Maule Valley. The authors show that both academia and government are decisive in cluster competitiveness, especially in supporting its evolutionary character through the introduction of new technology.

This paper proposes that Cultiva UChile replicated a THM that involved and articulated different actors to generate inclusive innovation through specialized extension services with generally positive results for farmers. The present analysis of this case will contribute to the existing literature on agricultural innovation and extension as one of the first studies to document the effects of the 
model on farmers in addition to the interactions between the actors involved. This work also contributes to the still scarce research on the THM and inclusive innovation as well as documenting a case of comprehensive extension.

\section{Materials and Methods}

To provide a description of Cultiva UChile, information was obtained from internal reports and consultations held with the management team. The information gathered focuses on the organization, governance, and operation of Cultiva UChile. The descriptive approach used involved reviewing the participation of different sectors of the THM (academia, government, and industry) in Cultiva UChile as well as their relationships. It is important to clarify that although Cultiva UChile was an initiative designed by a university, the public sector and industry were directly involved in its operation to the extent detailed in the results. Industry actors in this case included vegetable growers of the Santiago Metropolitan and O'Higgins Regions who received the extension services.

The assessment of Cultiva UChile focused on the direct effects of short-term results of an intervention. Agricultural extension service direct effect indicators usually include access, use, and the level of satisfaction (GDPRD et al., 2011). In choosing specific variables, we were aware that we needed to limit our scope as much as possible to aspects closely related to the operation of Cultiva UChile to avoid possible biases. To measure access, we used the number of recommendations that Cultiva UChile extension agents made to farmers during the delivery of advisory services. To measure use, an adoption index was estimated from the proportion of recommendations that farmers effectively implemented. Finally, satisfaction was measured as the farmers' evaluation of the extension service on a seven-point Likert scale. This information was obtained from surveys of 91 farmers out of the 139 who received advice from
Cultiva UChile during the 2019-2020 season. The other 48 farmers were not included because some of their information was missing or incomplete. The surveys were completed by an extension agent visiting in person each farmer at the begining of the extension service and immediately after it was complete. Farmers were also asked whether they carried out actions related to cooperation, innovation, and investment in the 12 months prior to the delivery of the service.

The information related to the Cultiva UChile evaluation was first analyzed using descriptive statistics. After applying this descriptive analysis, direct effect variables were transformed into dummies to form the dependent variable of our model. The dummy for access $\left(A C C E S S_{i}\right)$ had a value of one if the farmer received recommendations equal to or greater than the average for this variable across the whole sample or zero if the value was lower. The dummy for (USE) had a value of one if the farmer adoption index was equal to one hundred percent, i.e., the farmer implemented all recommendations from the Cultiva UChile extension agent, or zero if any recommendations were not implemented. The dummy variable for satisfaction $\left(S_{A T I S F}\right)$ had a value of one if the farmer's declared general satisfaction with the service was given a value of seven, i.e., the maximum rating, or zero if a value below seven was given.

To capture whether the farmers' recent experience was related to direct effects of the Cultiva UChile project, we estimated a binary logistic regression. This model, first described by Cox (1958), determines the relationship between a binary response variable and a set of independent variables (Table 1). In our case, the dependent variable $\left(D E_{i}\right)$ was a dummy with a value of one if for a given farmer (i), ACCESS, USE $E_{i}$, and $S A T I S F_{i}$ were valued as one and zero otherwise (i.e., if $A C C E S S_{i}, U S E_{i}$, and/or $S_{A T I S F_{i}}$ presented a different value from one). Thus, our model can be written as follows: 
Table 1. Description and definition of the variables used in the binary logistic regression

\begin{tabular}{|c|c|c|}
\hline Variables & Definition & $\%=1$ \\
\hline $\begin{array}{l}\text { Dependent } \\
\text { variable, DE }\end{array}$ & 1 if dummy variables ACCESS, USE, and SATISF are equal to 1,0 otherwise & 25.3 \\
\hline \multicolumn{3}{|l|}{$\begin{array}{l}\text { Independent } \\
\text { variables, }\end{array}$} \\
\hline INNOV & $\begin{array}{l}1 \text { if the farmer innovated in processes or products in the } 12 \text { months before the service } \\
\text { started, } 0 \text { otherwise }\end{array}$ & 34.1 \\
\hline $\mathrm{COOP}$ & $\begin{array}{l}1 \text { if the farmer collaborated with the government, academia, or other farmers in the } 12 \\
\text { months before the service started, } 0 \text { otherwise }\end{array}$ & 93.4 \\
\hline INVEST & $\begin{array}{l}1 \text { if the farmer improved his (her) physical capital in the } 12 \text { months before the service } \\
\text { started, } 0 \text { otherwise }\end{array}$ & 35.2 \\
\hline EFFIC & 1 if the farmer received extension services on the efficient use of resources, 0 otherwise & 19.8 \\
\hline PRACT & $\begin{array}{l}1 \text { if the farmer received extension services on cultivation and postharvest practices, } 0 \\
\text { otherwise }\end{array}$ & 23.1 \\
\hline PHYTO & 1 if the farmer received extension services on phytosanitary management, 0 otherwise & 44.0 \\
\hline MANAG & $\begin{array}{l}1 \text { if the farmer received extension services on marketing and business management, } 0 \\
\text { otherwise }\end{array}$ & 13.2 \\
\hline
\end{tabular}

$\operatorname{Logit}\left[P\left(D E_{i}\right)\right]=\alpha_{i}+\beta_{1} I N N O V i+\beta_{2} C O O P_{i}+\beta_{3}$ INVEST $_{i}+\beta_{4}$ EFFIC $_{i}+\beta_{5}$ PRACT $_{i}+\beta_{6}$ PHYTO $_{i}$ $+\beta_{7} M A N A G_{i}+u_{i}$

where $I N N O V_{i}$ is a dummy variable with a value of one if the farmer has innovated in process or products in the 12 months before the extension service started; $\mathrm{COOP}_{i}$ is a dummy variable with a value of one if the farmer collaborated with the government, academia, or other farmers in the 12 months before the service started; and INVEST is a dummy variable with a value of one if the farmer improved his (her) physical capital in the 12 months before the service started. We added to the model these variables related to the recent pathway of farmers in terms of innovation and associated conditions such as cooperation and investment in physical capital to prove whether they affect the direct effects of extension services. EFFIC $_{i}$, PRACT $_{i}$, PHYTO $_{i}$, and $M A N A G_{i}$ are dummy variables with a value of one if the farmer advisory area adopted an efficient use of resources, cultivation and postharvest practices, phytosanitary management, or marketing and business management, respectively. These variables allow us to prove whether the direct effects differ depending on the advisory area.
We applied a chi-square omnibus test to check the adequacy of the model and calculated Cox and Snell's $\mathrm{R}^{2}$ and Nagelkerke's $\mathrm{R}^{2}$ to measure its goodness of fit

\section{Results and Discussion}

The Cultiva UChile Center operated in 35 rural districts of the Chilean Central Valley with 14 in the Santiago Metro Region and 21 in the O'Higgins Region. The selection of these regions was based on two factors: they were the regions closest to the University of Chile, which is located in Santiago, facilitating in-person survey collection, and these regions include $45 \%$ of Chile's vegetable-producing acreage (INE, 2019). A total of 334 surveys were collected as a baseline by the center at the beginning of 2017, and the survey results show that vegetable farmers in the SMR and OHR were predominantly male and of a high average age. Their farms were small in scale, had unstable incomes, were planted in open-air fields, used furrow irrigation, accessed markets through intermediaries and wholesalers, and adopted rudimentary business management practices. The most common crops grown included potatoes, onions, garlic, tomatoes, and sweet corn 
in terms of land area. Rates of innovation, association and cooperation were low (Boza et al., 2020b). The center considered these features when refining the design of its structure and extension services.

Cultiva UChile was a 42-month project with a total budget of $1,363,016,611$ CLP $(1,917,176$ USD, $1 / 4 / 2021)$. CORFO covered $65.81 \%$ of the budget, and the remainder was covered through monetary and nonmonetary contributions from the University of Chile and three associated entities: government agencies of the Chilean Ministry of Agriculture, Agricultural Development Institute (INDAP) and Chilean Food Safety and Quality Agency and private research and agricultural development center the Rosario Assessment Center. Other entities that collaborated in Cultiva UChile activities were the University of O'Higgins, the Business Development Centers of the Chilean Technical Cooperation Service, and CORFO's Strategic Regional Program for the promotion of vegetable production in the OHR, Horticrece.

The associated and collaborating entities were part of the Cultiva UChile Advisory Council. The council met every four months. In addition to the entities mentioned, other actors were invited to the council, including the directors of the SMR and OHR Regional Ministerial Agriculture Services, a representative of the Inter-American Institute for Cooperation on Agriculture, a representative of the Chilean Agricultural Research Institute, and farmers who were association leaders or considered exemplary or especially innovative. The council meetings served as a space for exchanging information where those working directly on Cultiva UChile updated the council on their actions and received feedback, while the participating entities shared their initiatives and thoughts on how they could be integrated into the activities of the center and its beneficiaries.

Cultiva UChile served a total of 283 microlevel-, small-, and medium-scale vegetable farmers sized according to the Chilean Ministry of Economy's scale (Law 20.416). Extension services were preceded by a comprehensive diagnosis for each farm based on a specialized advisory. The farmers' strengths and weaknesses were identified to adapt to their needs. The extension services focused on at least one of the following four areas: i) marketing and business management, ii) the efficient use of resources, iii) phytosanitary management, and iv) cultivation and postharvest practices, which were divided into 39 different "priorities", i.e., specific actions such as "defining a business model" or "proposing an integrated pest management strategy." The farmers' field advisory was led by a team of eight professionals: four technical and production specialists; two marketing and management specialists; and two professionals in charge of the generation of networks and personal connections between actors in each area. This team was guided by academic staff of the University of Chile, providing them access to cutting-edge innovations from academia.

The advisory services lasted between 3 and 8 months. Usually, technical and productive consultations took place during the productive season and lasted six to eight months. Commercial and managerial services usually took place outside of the productive season and lasted three to six months. Either way, the services always started with a diagnosis and selection of priorities. The extension agents then designed a personalized work strategy, and the farmer received theoretical and practical training to develop a work strategy. During this process, the extension agents visited the farmer two to four more times to follow the progress of the work strategy and provide feedback. Finally, the extension agents collected additional information to evaluate the impact of the service. Advisory services were always accompanied by efforts to connect farmers to public institutions, especially by providing information and support for applying to the available promotional programs.

In addition to providing advisory services, Cultiva UChile maintained activities in technological dissemination and specialized training. The former targeted farmers, involving a total of 641 
participants during the project. The latter targeted field professionals, especially those from the INDAP, with a focus on aspects of innovation and technology for vegetable production and on how to conduct more effective agricultural extension. A total of 69 professionals were trained. Furthermore, in 2020, Cultiva UChile collaborated with the Chilean Ministry of Agriculture, CORFO, and the Fruit Exporters Association to define the horticultural territorial strategy of the SMR.

Cultiva UChile reported its activities to CORFO every month. These reports were focused on the coverage and progress of each extension service. Once a year, the center presented an impact report of its services to CORFO based on the information that the extension agents collected from each farmer. This information was organized in standardized spreadsheets used by all extension centers funded by CORFO to be compared.

A synthesis of the direct effects of the Cultiva UChile extension service on our sample is shown in Table 2.

Access: Farmers received a minimum of one and a maximum of seven recommendations. Most farmers $(70.3 \%)$ received three or fewer recommendations, $43.95 \%$ of farmers were advised on phytosanitary management, $23.97 \%$ were advised on cultivation and postharvest practices, $19.78 \%$ were advised on the efficient use of resources, and $12.3 \%$ were advised on marketing and management. In Chile, two features that characterize conventional small-scale vegetable farmers include a high use of artificial fertilizers and pesticides and selling to intermediaries (Rossing et al., 2020). The distribution of extension services by area was coherent with these characteristics.

Use: The average adoption index of the recommendations was $89.7 \%$, and $76.9 \%$ of farmers had an adoption index of $100 \%$, i.e., they applied all recommendations received from the Cultiva UChile team during extension services. This adoption rate is high, especially since previous research on Chilean small-scale vegetable growers shows that this group is often averse to change (Boza et al., 2020b). The distribution of the adoption index was similar regardless of the area of the advisory, except in the case of cultivation and postharvest practices, for which only $57.1 \%$ of farmers had an adoption index of $100 \%$. Changes in this area may have been more demanding for farmers.

Table 2. Synthesis of direct effect indicators for Cultiva UChile services

\begin{tabular}{|c|c|c|c|c|}
\hline Category & Indicator & Values & Farmers & $\%$ \\
\hline \multirow[t]{7}{*}{ Access } & Number of recommendations received & 7 & 5 & 5.5 \\
\hline & & 6 & 3 & 3.3 \\
\hline & & 5 & 9 & 9.9 \\
\hline & & 4 & 10 & 11.0 \\
\hline & & 3 & 27 & 29.7 \\
\hline & & 2 & 27 & 29.7 \\
\hline & & 1 & 10 & 11.0 \\
\hline \multirow[t]{4}{*}{ Use } & Adoption index & $100 \%$ & 70 & 76.9 \\
\hline & & $75-99 \%$ & 6 & 6.6 \\
\hline & & $50-74 \%$ & 10 & 11.0 \\
\hline & & $<50 \%$ & 5 & 5.5 \\
\hline \multirow[t]{7}{*}{ Satisfaction } & General satisfaction with the service & 7 & 66 & 72.5 \\
\hline & & 6 & 23 & 25.3 \\
\hline & & 5 & 2 & 2.2 \\
\hline & & 4 & 0 & 0.0 \\
\hline & & 3 & 0 & 0.0 \\
\hline & & 2 & 0 & 0.0 \\
\hline & & 1 & 0 & 0.0 \\
\hline
\end{tabular}


Satisfaction: The average score for this variable was measured as 6.7 out of 7.0. A total of $72.5 \%$ of farmers gave a score of $7.0,25.3 \%$ of farmers gave a score of 6.0 , and $2.2 \%$ of farmers gave a score of 5.0. Each specific aspect related to the service had an average score from 6.6 to 6.9. All of the farmers said that they would recommend Cultiva UChile services to other farmers and that they would be willing to receive Cultiva UChile services again in the future. These results reflect very positively on the performance of Cultiva UChile, as the most direct short-term measure assessing the operations of an agricultural service is its users' level of satisfaction (GDPRD et al., 2011).

Regarding the results for the binary logistic regression (Table 3), none of the variables in the model show a significant probability of a farmer experiencing strong direct effects from Cultiva UChile extension services. In fact, despite the chisquare omnibus test supporting the adequacy of the model, the results of the goodness of fit tests are low. These results show that the direct effects of the extension services (dependent variable) were

Table 3. Results of binary logistic regression estimation for direct effects

\begin{tabular}{lcc}
\hline Variables & \multicolumn{2}{c}{ Model results } \\
\hline Dependent: DE & $\begin{array}{l}\text { Coefficient } \\
\text { (odds ratio) }\end{array}$ & Sig. \\
Constant & -1.237 & 0.331 \\
INNOV & -0.711 & 0.286 \\
COOP & -0.620 & 0.488 \\
INVEST & 0.581 & 0.376 \\
EFFIC & 1.210 & 0.170 \\
PRACT & - & - \\
PHYTO & 1.110 & 0.207 \\
MANAG & -19.207 & 0.999 \\
& \multicolumn{3}{c}{$13.643^{*}(0.034)$} \\
Chi-square omnibus test & \multicolumn{2}{c}{89.248} \\
Log-likelihood & \multicolumn{2}{c}{0.139} \\
Cox and Snell R $\mathrm{R}^{2}$ & \multicolumn{2}{c}{0.206} \\
Nagelkerke's R ${ }^{2}$ & \multicolumn{2}{c}{91} \\
$\mathrm{~N}$ & \multicolumn{2}{c}{} \\
\hline
\end{tabular}

${ }^{*}$ indicates significance at the $5 \%$ significance level. transversal to farmers regardless of their recent experiences with innovation, cooperation with others, or investment in on-farm infrastructure.

We suggest that these results support our assumption that Cultiva UChile extension services promoted inclusive innovation, not only because the center served small-scale farmers but also because it even transcended the differences between them. This is particularly important due to the considerable heterogeneity of small-scale farming (FAO, 2020).

\section{Conclusions}

The objective of this article was to show how agricultural extension can work based on the THM to enable inclusive innovation and to evaluate its effects on farmers considering their paths. We analyzed horticultural extension service Cultiva UChile, a technology transfer center that offered comprehensive consulting to small-scale vegetable growers in central Chile. We observed strong interactions between actors as a basis for the operation of the THM. In this case, the public sector identified innovation gaps and provided financing for centers that aimed to mitigate them, chose centers to fund, and monitored their operation. The public sector also participated as a coexecutor and counselor, which promoted the exchange of information and coordination. The involved university was responsible for the administration and accountability of the center, for bringing the different actors together, and for providing extension services based on research and innovation generated by the university itself. The targeted industry was that of vegetable growers, who were the "clients" of extension services. Their role was not at all passive, however, since they were responsible for implementing the recommendations they received from the university team on their farms during the service. To facilitate this implementation, vegetable growers were trained and supported by the center. Vegetable growers also accessed further information on public sector promotion programs through the 
university. Through the Cultiva UChile experience, academia also connected with the public sector and industry through specialized training via a process of knowledge dissemination.

Our results show how agricultural extension based on the THM has positive short-term direct effects on access, use and satisfaction regardless of farmers' previous paths in key differentiating aspects such as innovation, cooperation, and investment in physical capital. These generalized positive effects suggest that the center was inclusive not only in its focus on an industry dominated by small-scale farmers but also that the pathway involved did not condition the short-term outcomes obtained.

From our results, we can make some recommendations for future programs. First, extension services under the THM can be an appropriate means to promote inclusive innovation in agriculture. For this strategy to work, the different sectors involved need to operate interrelatedly through a continuous exchange of knowledge and information. The public sector should go beyond funding and serve as an effective partner. Academia as a research and extension institution should reduce transaction costs and promote bilateral synergy between both activities. Farmers should have an active role in committing to implementing extension agents' recommendations and providing feedback used to improve the extension agency's program. The fact that farmers have already paid for a service's copayment (although it should be low enough to not be exclusive); constant follow-up by extension agents through visits and telephone communication; and realistic, actionable and context-specific recommendations can be central to increasing farmer engagement.

\section{Acknowledgments}

This research was developed under the "Horticultural Extension Center" project funded by the INNOVA-CORFO "Technological Extension Center" grant, "Healthy Foods" line. The authors also thank the professionals who collaborated in the surveys' application.

\title{
Resumen
}

\begin{abstract}
S. Boza, M. Espinoza, R. Pertuzé, M. Mora, y K. Orellana. 2021. Descripción y evaluación de un programa colaborativo de extensión agrícola bajo el Modelo de Innovación de la Triple Hélice. Int. J. Agric. Nat. Resour. 248-258. El Modelo de la Triple Hélice (MTH) estudia la interacción entre universidad, industria y gobierno para promover el emprendimiento y la innovación en el contexto de una sociedad basada en el conocimiento. El objetivo de este artículo es ilustrar el funcionamiento de la extensión agrícola para la generación de innovación inclusiva bajo el MTH y evaluar sus efectos en los agricultores. Para ello, analizamos el caso de Cultiva UChile, un centro de transferencia de tecnología liderado por la Universidad de Chile que operó de 2016 a 2020, financiado y en cooperación con organismos del sector público. Cultiva UChile ofreció servicios de extensión a productores de hortalizas del Valle Central de Chile. Las principales fuentes de información fueron informes internos y encuestas a 91 agricultores que recibieron los servicios de extensión de Cultiva UChile en la temporada 2019-2020. Se aplicó un análisis cualitativo sobre la organización, actores, funcionamiento y gobernanza del Centro y un análisis cuantitativo de sus efectos directos; lo segundo, mediante técnicas descriptivas y regresión logística binaria. Los resultados muestran fuertes interacciones entre los actores como la base de la operación de Cultiva UChile, así como sus efectos directos positivos a corto plazo, independientemente de la trayectoria previa de los agricultores en innovación, cooperación e inversión. Estos resultados nos llevan a concluir que los servicios de extensión bajo el MTH pueden ser apropiados para promover la innovación inclusiva en la agricultura.
\end{abstract}

Keywords: Efectos directos, horticultura, servicios de extensión, pequeña agricultura. 


\section{References}

Armando, E., Gama Boaventura, J.M., Todeva, E., \& Costa Pereira, C.E. (2017). Triple Helix Influence on Competitiveness Factors: Comparison Between Wine Clusters in Brazil and Chile. Revista Eletrônica de Negócios Internacionais, 12(3), 43-60. https://doi.org/10.18568/19804865.12343-60.

Aron, J. (2003). Building institutions in post-conflict African economies. Journal of International Development, 15, 471-485. https://doi.org/10.1002/ jid.997.

Boza, S., Muñoz, J., Núñez, A., \& Díaz-Lanchas, J. (2020a). Dinámica de las exportaciones frutícolas chilenas desde una perspectiva regional (2008-2018). Chilean Journal of Agriculture and Animal Sciences, 36(1), 26-34. https://doi. org/10.4067/S0719-38902020005000103.

Boza, S., Cortés, M., Prieto, C., Muñoz, T., \& Mora, M. (2020b). Characteristics and attitudes of small-scale vegetable farmers in Chile. Ciência Rural, 50(10), e20191025. https://doi. org/10.1590/0103-8478cr20191025.

Breznitz, S.M., \& Feldman, M.P. (2012). The larger role of the university in economic development: introduction to the special issue. The Journal of Technology Transfer, 37, 135-138. https://doi. org/10.1007/s10961-010-9184-5.

Bruce, K., \& Costa, F. (2019). Enabling environment for PPPs in agricultural extension projects: Policy imperatives for impact. Journal of Rural Studies, 70, 87-95. https://doi.org/10.1016/j. jrurstud.2019.07.005.

Chacana, M., Geldes, C., \& Osorio, H. (2019). El rol de la proximidad en la cooperación universidad-empresa-gobierno: el caso del sector agroalimentario de la Región de Coquimbo, Chile. Universidad \& Empresa, 21(36), 61-78. https://doi.org/10.12804/revistas.urosario.edu. co/empresa/a.6057.

Cox, D.R. (1958). The Regression Analysis of Binary Sequences. Journal of the Royal Statistical Society. Series B (Methodological), 20(2), 215-242.

Dalmarco, G., Hulsink, W., \& Zawislak, P.A. (2019). New perspectives on university-industry rela- tions: an analysis of the knowledge flow within two sectors and two countries. Technology Analysis \& Strategic Management, 31(11), 13141326. https://doi.org/10.1080/09537325.2019.1 612868

Daniels, C.U., Ustyuzhantseva, O., \& Yao, W. (2017). Innovation for inclusive development, public policy support and triple helix: perspectives from BRICS. African Journal of Science, Technology, Innovation and Development, 9, 513-527. https://doi.org/10.1080/20421338.201 7.1327923.

Derunova, E. (2021). Conditions for the development of the institutional structure of the scientific and intellectual potential of the agricultural food complex. Management, Economic Engineering in Agriculture \& Rural Development, 21(1), 197-205.

Echeverría, R., Moreira, V., Barrena, J., \& Gopinath, M. (2012). A characterization of Chilean farmers based on their market-production orientation. Ciencia e Investigación Agraria, 39, 255-264. https://doi.org/10.7764/rcia.v39i2.58.

Etzkowitz, H., \& Leydesdorff, L. (1995). The Triple Helix. University-Industry-Government Relations: A Laboratory for Knowledge-Based Economic Development. EASST Review, 14, 14-19.

Etzkowitz, H., \& Zhou, C. (2017). The Triple Helix University-Industry-Government Innovation and Entrepreneurship. Routledge, London.

FAO. (2020). The state of agricultural commodity markets. FAO, Rome.

GDPRD, FAO \& World Bank. (2011). Seguimiento de resultados en la agricultura y el desarrollo rural en condiciones no ideales. FAO, Rome. http://www.fao.org/3/a-i0380s.pdf

Geldes, C., Heredia, J., Felzensztein, C., \& Mora, M. (2017). Proximity as determinant of business cooperation for technological and non-technological innovations: a study of an agribusiness cluster. Journal of Business \& Industrial Marketing, 32(1), 167-178. https://doi.org/10.1108/ JBIM-01-2016-0003.

Heeks, R., Foster, C., \& Nugroho, Y. (2014). New models of inclusive innovation for development. 
Innovation and Development, 4(2), 175-185. https://doi.org/10.1080/2157930X.2014.928982.

Hellin, J., \& Camacho, C. (2016). Agricultural research organizations' role in the emergence of agricultural innovation systems. Development in practice, 27(1), 111-115. https://doi.org/10.1080 /09614524.2017.1256373.

INE - Chile. (2019). Encuesta de superficie hortícola. https://www.ine.cl/estadisticas/economia/ agricultura-agroindustria-y-pesca/hortalizas

Klerkx, L., Aarts, N., \& Leeuwis, C. (2010). Adaptive management in agricultural innovation systems: The interactions between innovation networks and their environment. Agricultural Systems, 103(6), 390-400. https://doi.org/10.1016/j. agsy.2010.03.012.

Klerkx, L., Van Mierlo, B., \& Leeuwis, C. (2012). Evolution of systems approaches to agricultural innovation: concepts, analysis and interventions. In: Darnhofer, I., Gibbon, D. \& Dedieu, B. (Eds.). Farming Systems Research into the 21st Century: The New Dynamic. (pp. 457-483). Springer, Berlin.

Knickel, M., Neuberg, S., Klerkx, L., Knickel, K., Brunori, G., \& Saatkamp, H. (2021). Strengthening the Role of Academic Institutions and Innovation Brokers in Agri-Food Innovation: Towards Hybridisation in Cross-Border Cooperation. Sustainability, 13(9), 4899. https://doi. org/10.3390/su13094899.

MINECON. (2018). Décima Encuesta innovación en empresas (2015-2016). Retrieved from: https://www.economia.gob.cl/wp-content/uploads/2018/02/Beamer_Innova_2015_2016-3.pdf.
Norton, G.W., \& Alwang, J. (2020). Changes in Agricultural Extension and Implications for Farmer Adoption of New Practices. Applied Economic Perspectives and Policy, 42(1), 8-20. https://doi. org/10.1002/aepp.13008.

Reddy, P. (2011). The Evolving Role of Universities in Economic Development: The Case of University-Industry Linkages. In: Göransson, B. \& Brundenius, C. (Eds.). Universities in Transition: The Changing Role and Challenges for Academic Institutions. (pp. 25-49). Springer, Berlin.

Rossing, W., Kormelinck, A.G., Alliaume, F., Dogliotti, S., Duncan, J., Huenchuleo, C., Klerkx, L., Trienekens, J., \& Gaitán-Cremaschi, D. (2020). Transitioning to the safe and just space inside 'the doughnut' by means of agroecological niche food systems: insights from Chile and Uruguay. International Journal of Agriculture and Natural Resources, 47(3), 295-311. https://doi. org/10.7764/ijanr.v47i3.2258.

Steensland, A., \& Zeigler, M. (2021). Productivity in Agriculture for a Sustainable Future. Springer, Berlin.

Yao, W., Li, H., \& Weng, M. (2018). The Role the University Could Play in an Inclusive Regional Innovation System. Triple Helix, 5, 12. https:// doi.org/10.1186/s40604-018-0058-4.

Yongabo, P., \& Göktepe-Huiltén, D. (2021). Emergence of an agriculture innovation system in Rwanda: Stakeholders and policies as points of departure. Industry and Higher Education, 20(10)., 1-16. https://doi. org/10.1177/0950422221998610. 